\title{
Problems in Bureaucratic Planning Process Supporting Quality of Public Services
}

\author{
Podungge Wahab Abdul, Asna Aneta, Ansar Made, Juriko Abdussamad
}

Doctoral Program of Administrative Science, State University of Gorontalo, Indonesia

\begin{abstract}
The article aimed to analyze and describe the process of public service management in DPMPTSP Gorontalo in terms of its organization planning process. The research method used was qualitative. Data analysis used was interactive model analysis consisting of three analysis components i.e. 1) data reduction, 2) data presentation and 3) data verification and conclusion drawing.

Research findings indicated that the planning process should be supported by the rule of law aspect. The enforcement in rule of law as the research findings was as follows: 1) service mechanism in DPM-PTSP required regulating power to optimize organizational function, 2) the regulation aspect should be reviewed adequately to ensure legal protection was given to service innovation made by employees, 3) regulations available in DPM-PTSP Gorontalo were overlapping. It restricts the director to stipulate planning standards as one of the corrective acts in DPM-PTSP services, 4) rule of law could selected mechanism and protect all employees, so a transparent, accountable, effective and efficient public service could be achieved and 5) optimization in regulation might elevate public service quality, develop an investment climate and increase both regional and national economic growth.
\end{abstract}

Keywords-Public Service Management, Planning Process, License.

\section{INTRODUCTION}

\subsection{Research Background}

Licensing procedures in Indonesia are complicated and hard to trace, blocking any business activities. There are numerous types of licensing in Indonesia. The problem in understanding who has the authority and responsibility is still difficult to deal with. People still have no idea of, ex. who is responsible for their license, whether it is the regency, province, or the state. The authority problem commonly relates to the type of business being run, capacity, and the business area.

Bureaucracy should not only serve the public but also manage public policy. It greatly contributes to making public policy as well as policy implementation, strengthening, and evaluation. To solve problems in the convoluted licensing service, the government founded a licensing organization to eliminate any public stigma that public service by the government gives much trouble; such as convolution, confusing requirements, and inflexible regulation.

Gorontalo is progressively advancing from year to year in terms of infrastructure and enterprise establishment, either conventional or modern. It implies more investors are investing in this particular area. Therefore, the government of Gorontalo established Organisasidan Tata Kerja Unit Pelayanan Perizinan Satu Atap(English: Organization and Work Procedure of One-stop Licensing Service Unit). The organization and work procedure was then developed into an integrated licensing service center or DPM-PTSP. It is determined to ease the licensing process in Gorontalo and draw interests of small micromedium enterprise actors and non-Gorontalo investors. It optimizes its role as a public service organizer by continuously optimize service mechanism in accordance with two primary service principles i.e. easy and simple. As a result, the public as the economic actors are satisfied due to fulfilled demand. DPMP-PTSP relies on the Law Number 25 of 2009 on Public Service to organize their service.

Based on our observation on the quality of public service in DPM-PTSP Gorontalo, their public service concept did not comply with the goals of Good Governance and was not well implemented. The implications of the bureaucracy are ineffective and inefficient performance of employees. Besides, apparatus resources provide incompetent services. Mentality and 
intention to provide public services are also still minimum. We found several problems in DPM-PTSP i.e.:

Firstly, DPM-PTSP was only equipped with limited human resources. Employees worked daily and served at least 10-20 applicants, either licensing or nonlicensing applicants. The employees were overwhelmed in providing services. Consequently, piling documents were in the ticket window. It took 15-20 minutes to serve one client who needed consultation. Many of the applicants had to be willing to wait all day long.

Secondly, employees lacked information about licensing and non-licensing service implementation in DPM-PTSP. In consequently, employee competence was uneven. Some employees, especially front officer placed in the service window did not thoroughly understand several licensing and non-licensing points frequently asked by applicants. The undetailed answers baffled them. They were suggested to have a consultation with back officers or the director. Consequently, applicants should repetitively go to the Center and submit any required files due to unclear requirement explanation. Employees lacked knowledge, as they did not have any educational background required. They came from different OrganisasiPerangkat Daerah (English: Regional Apparatus Organization), even some of them were teachers. They were suddenly instructed to serve public license, a job they never dealt with. Therefore, it took a long time to uniform their perception and knowledge. They had to comprehend all licensing subjects, from registration, licensing requirements, payment to file retrieval.

Thirdly, the online system DPM-PTSP currently implemented through Portal Kota Gorontalodid not provide enough easiness for public, making them complain. Pubic found errors while accessing the site, as the service providers did not respond and were temporarily inactive sometimes. Consequently, people should re-input their data. Furthermore, the system did not give enough information about the licensing management component and the licensing itself, so face-to-face consultation in the Center was preferable.

Fourthly, communication between people and applicants was ineffective. Our findings indicated that there were several people complained of unclear information DPM-PTSP employees provided for. Employees requested their phone numbers and told them that they would be informed by phone when their licensing file was ready. However, the information was not received after one or even two weeks later. The lateness made people actively ask and search for any required information. In addition, in-licensing which needed field survey; such as Building Permit, they had to wait for the survey which was never done.

We also found other issues i.e. a) Some heads of department in the Local Government of Gorontalo were unwilling to give their authorities to DPM-PTSP Gorontalo, b) In term of licensing process, DPM-PTSP Gorontalo should be granted accessibility to each department, so they could request assistance to the departments while needing a professional opinion or help in managing licensing files. DPM-PTSP had limited human resources. They did not have experts in certain subjects; such as engineer, environmentalist, medical worker, and others, c) There was regulation disharmony. DPM-TSP was established based on the Regulation of the Minister of Home Affairs Number 20 of 2008 on Guidelines for Local Organization and Integrated Service Work Procedures. Meanwhile, there was another regulation which was President Regulation Number 27 the year 2009 on PTSP in Capital Investment. The regulation dealt with the same objects but with different authorities and regulations, creating overlapping regulations. In terms of authorities, there were two instructors which were the Minister of Home Affairs and the Capital Investment Coordinating Board with two overlapping authorities.

We were informed by the data that Gorontalo Public Service Compliance Standards had declined. Data released by Ombudsman of the Republic of Indonesia in 2017 confirmed that public service compliance standards in Gorontalo were severe (red). The Ombudsman assumed the severity was due to weaknesses and ineffectiveness in public service which, obviously required corrective acts. Service transformation the government gave through DPM-PTSP had been well implemented regardless of violations and unwillingness to serve showed by the apparatuses. For example, in terms of the license, many people proposed reporting files to Ombudsman, complaining how hard it was to get a license when the legislation clearly stated that all instance authorities were in one integrated service unit.

Based on potential investment data in Gorontalo we collected in the Central Bureau of Statistics of Gorontalo, 1) Tourism sector was one of the iconic sectors that might boost Gorontalo Local Own-source Revenue. Gorontalo tourism had attracted both domestic and international tourists, so the government should be determined to develop the sector. Facilities and management for tourism destinations were still inadequate, so both government and private institutions should cooperate in their development. Potential investment might be in luxurious hotels, tourism-travel agency, entertainment facilities, recreational places, and art and 
culture studio; 2) the Health sector was also one of the most prioritized programs in Gorontalo. Ensuring public health, the Health Office continuously made efforts in the implementation of early disease diagnosis. The efforts were manifested in various health activities. The cardiac medical center had been available in RumahSakitUmum Aloe SaboeGorontalo. However, Gorontalo had few hospitals, causing many patients to remain abandoned. Available hospitals could not treat and take care of all patients due to insufficient medical tools and drugs. The hospitals, especially the private ones should also suffer from lack of investment, medical facilities, drug distribution, and health workers, 3) Most industry sectors in Gorontalo were home industries developed based on their human resources' competence and skills. The local government had supported the existing home industries and encouraged them to develop. Besides, the government also gave relevant training, making the industries able to innovate and thus able to compete with other industries in other regions. The most prominent industry in Gorontalo was furniture, snack, and karawo embroidery industries. The investment opportunity might be up to $60 \%$ (furniture and snack) and 4) In terms of the trading sector, there were two enterprise units i.e. micro and small-medium enterprises. The two enterprise units came with varied investment values. All of those enterprises were managed and regulated by the local government with their ownership/legality status. The potential investment might be made in mall development (Central Bureau of Statistics of Gorontalo, 2018).

The data we had elaborated implied some potentials the government could be managed and developed to sustain local economic growth. Unfortunately, the potentials were not optimized due to challenges in the licensing process. For instance, home industries were dominant in Gorontalo. If the government was eager to enlighten them to get a legal license, they would earn another income from the income tax paid by the industries. The industries did online marketing and did not pay any tax.

Therefore, to enhance local potencies through investment growth, an effective and efficient management process in DPM-PTSP Gorontalo is required. Terry (2000) formulates four measuring indicators i.e. 1) Planning: a basic process in which management determines the goals and methods to achieve them, 2) Organizing: how management groups their activities. Each group is equipped by a leader given authority to manage his/her group, 3) Implementing: how management motivates group members so they are willing and struggling to reach the organization goal and the organization member goals and 4) Monitoring/controlling: how management determines what to achieve and evaluate as well as determines corrective acts if necessary, ensuring all activities to be in line with the plan.

\subsection{Research Objectives}

Based on the research context, our research problem deals with public service management in Dinas Penanaman Modal dan Pelayanan Terpadu Satu Pintu (English: Investment and One-stop Licensing Service Office) Gorontalo in term of its planning process.

\section{RESEARCH METHODS}

The research method used was qualitative. Data analysis used was interactive model analysis consisting of three analysis components i.e. 1) data reduction, 2) data presentation and 3) data verification and conclusion drawing (Miles and Huberman, 1992).

Key informants were 1) director, front officer, back officer and staff of DPM-PTSP Gorontalo, 2) applicants and 3) members of Regional House of People's Representatives (DPRD) Gorontalo.

\section{RESEARCH FINDINGS AND DISCUSSION}

A reliable service area should satisfy the public by its services. Therefore, as a public policy stakeholder, bureaucracy should develop integrity in its services. Planning in the development of public service quality aimed to assess that the latest innovation and program was applicable. Besides, planning aimed to assist management while adapting to changes in environmental. Furthermore, it also helped management face the main problems and enabled the director to understand the whole picture of the organization. In addition, it contributed to placing employees in accordance with their capability and in giving operational instructions correctly.

Effendy (2015:84) proposed four reasons why planning was necessary. The four reasons were: 1) Planning was the director. Planning directed employees and gave them knowledge of where the organization should be run into and what they should do to achieve the organization's goals. The employees might be led to nowhere or opposite directions when planning was absent. As a result, an organization would make no progress, 2) Planning could anticipate the impact of changes. Planning could motivate employees to look further, to anticipate changes, and to consider the effects. Planning could make consequences clear, 3) Planning could minimize any 
wasteful activity. Planning eliminated financial waste and overlapping activities. Besides, facilities needed and goals would be clear, ineffectiveness would be revealed and corrected or eliminated and 4) Planning was a measure. Planning could be used to control an activity implementation. Violation, if happening, might be easily identified and corrective acts could be immediately taken. Furthermore, the director might be able to compare actual performances to the organization target and to identify violations and to take necessary corrective acts. Controlling was impossible without planning.

Therefore, the first step to take should be the implementation of simple and easy service procedures which are in accordance with the applicable regulation. Brief and efficient service procedures will punctuate the service, making it finished on time. Law Number 25 of 2009 demands service standards applied in all government institutions which manage public services.

Our informants conveyed that planning was necessary for the organization to anticipate any future challenges. One of the DPM-PTSP employees explained the most anticipated challenge which was to design a licensing and non-licensing service system that was quickly integrated, simple, and punctual. The design should comply with applicable regulations. Therefore, the director of DPM-PTSP Gorontalo should evenly distribute licensing services to all instances in Gorontalo. The distribution was eventually taken into account and regulated by the Regulation of the Major of Gorontalo Number 4 of 2017 on Delegation of Licensing and Nonlicensing Services to Investment and One-stop Licensing Service Office. Finally, there were 92 types of licensing delegated to DPM-PTSP Gorontalo in 2018.

Anticipating the development of technology, DPM-PTSP Gorontalo made an innovation in its egovernment-based service. They had used applicable technology to manage licensing documents since early 2018. Our data showed that licensing and non-licensing documents successfully managed were 4,104 in 2017 and rapidly increased by 4,523 prior December 2018. The number would hopefully increase at the end of December 2018.

DPM-PTSP had launched an application Sicantik (abbreviated form of CerdasLayananPerizinanTerpaduuntuk Public, or Smart Integrated Licensing Service for Public). The application helped people manage licenses for business or nonbusiness activities. In addition to ease people, the licensing service was more efficient and faster. People could also control to what extent their documents had been processed.
In addition to Sicantik, DPM-PTSP Gorontalo also had used an application Online Single Submission (OSS) directly integrated with the central government. By the application, all licensing activities were accessible and could be monitored by the central government. As a result, investment development could also be directly monitored by the central government, either by the Ministry for Economic Affairs, Commercial Ministry, or BKPM. Both applications had been operated. Furthermore, DPM-PTSP had released an electronic signature facility, enabling all licenses could be managed online although the director of the Office was absent. They could get his/her signature using their smartphone. It was then expected that there would be no licensing service postponed after the facility was released. DPM-PTSP hoped that people would no longer find difficulties in getting a license to develop their business and find a solution with a minimum fee.

One of our informants, a member of the Regional House of People's Representatives Gorontalo mentioned that Gorontalo was being one of the cities which drew investors' interests. Numerous investors had gradually invested in Gorontalo. DPRD, with the local government, was highly committed to developing Gorontalo. In terms of regulation, DPRD and local government had managed the development well. The local government had issued a regulation on buildings, a regulation which determined how investors were allowed to make an investment in Gorontalo. Therefore, when having a discussion with the local government, DPRD studies all kinds of stuff about investment thoroughly and carefully. As a result, small and large investors planning to invest in Gorontalo would earn profit and be aware of investment regulations applied in Gorontalo. Investors were well welcomed by DPRD. They could help in economic growth in Gorontalo and hired many people. Gorontalo had been widely known as a service city. Investors might bold the impression.

We viewed that service innovation offered by DPM-PTSP Gorontalo could be implemented as long as it complied with the regulation. Various aspects, including regulation, should be considered. The regulation consideration was the most fundamental issue, as a government organization should be in accordance with the legal rule. Many innovations offered by local heads made them violate legal acts. Thus, innovations made should be reviewed and agreed by local heads, ministries, and the president. Besides, necessary regulation was required to protect policies to be issued.

We found these following planning processes i.e. 1) Determining the organization goals, 2) Developing logics for future conditions, and 3) Implementing the planned activities and evaluate the result. We proved that 
planning for licensing and capital investment service management policy in DPM-PTSP Gorontalo had been in accordance with applicable legislation and mechanism. One of the planned services that had been implemented was to make all types of licensing available in all SKPD in Gorontalo were delegated to DPM-PTSP. The delegation was successfully managed after the issuance of the Regulation of Major Number 4 of 2017 on Delegation of
Licensing and Non-licensing Services to Investment and One-stop Licensing Service Office. Eventually, 10 types of licensing in 2017 were leveled up to 92 at the end of 2018. All licensing was delegated to DPM-PTSP Gorontalo. The government wanted to change the public perspective that the licensing service was not complicated, wasting time, ineffective and inefficient anymore. As a result, investors would put more interest and increased economic growth.

Table.1: Findings in Public Service Management Planning by DPM-PTSP Gorontalo

\begin{tabular}{|c|c|c|c|c|c|}
\hline \multirow{3}{*}{ No. } & \multirow{3}{*}{$\begin{array}{c}\text { Assessed } \\
\text { Aspect }\end{array}$} & \multicolumn{4}{|c|}{ Research Findings } \\
\hline & & \multicolumn{2}{|c|}{ Plus } & \multicolumn{2}{|c|}{ Minus } \\
\hline & & Findings & Implication & Findings & Implication \\
\hline & \multirow[t]{2}{*}{$\begin{array}{c}\text { Planning } \\
\text { process }\end{array}$} & $\begin{array}{l}\text { The issuance of the } \\
\text { Regulation of Major } \\
\text { Number } 4 \text { of } 2017 \text { on } \\
\text { Service Authority } \\
\text { Delegation to DPM- } \\
\text { PTSP Gorontalo }\end{array}$ & $\begin{array}{l}92 \text { types of } \\
\text { licensing were } \\
\text { successfully } \\
\text { managed (the } \\
\text { early types } \\
\text { managed were } \\
\text { ten) }\end{array}$ & $\begin{array}{l}\text { Overlapping } \\
\text { regulation } \\
\text { which } \\
\text { hampered the } \\
\text { organization } \\
\text { performance }\end{array}$ & $\begin{array}{l}\text { Director should } \\
\text { consult to more } \\
\text { people while } \\
\text { making a } \\
\text { decision, } \\
\text { prolonging the } \\
\text { service }\end{array}$ \\
\hline & & $\begin{array}{l}\text { Increase in the number } \\
\text { of licensing and non- } \\
\text { licensing services }\end{array}$ & $\begin{array}{l}\text { Investment in } \\
\text { Gorontalo } \\
\text { increased }\end{array}$ & - & - \\
\hline
\end{tabular}

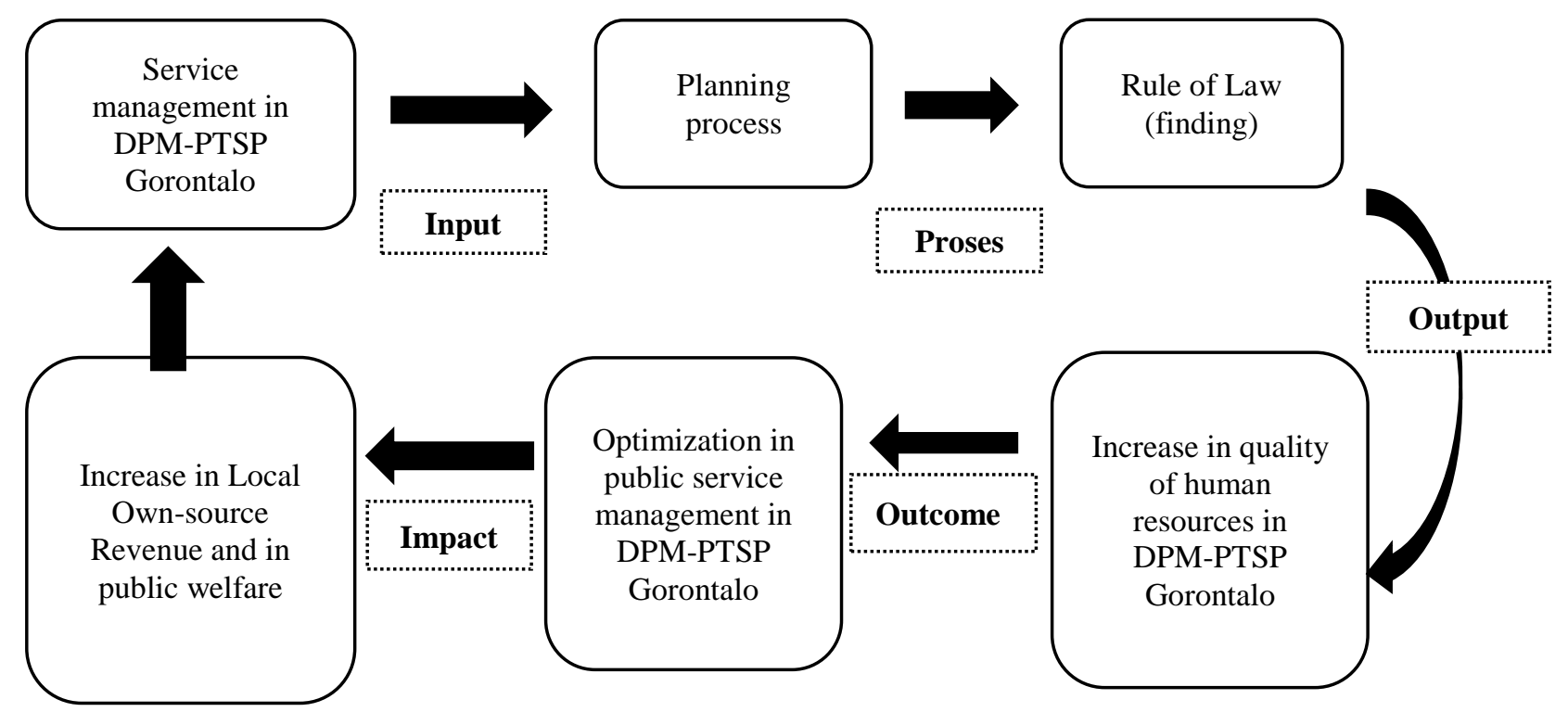

Fig.1: Findings in Public Service Management Planning by DPM-PTSP Gorontalo

The findings were in line with Siagian (2012), that planning constituted all logic processes regarding future actions performed to achieve the set goals. Terry (2002) supported in her statement that planning was the 
process of selecting and linking evidence, of making and using assumptions to formulate and design certain activities that were potentially required to achieve a certain goal.

Referring to the experts' arguments, our assumption was correct that Rule of Law was an integral part of a planning process conducted by the organization, or DPM-PTSP Gorontalo in term of public service. Rule of Law constituted a process that determined how the organization achieved a certain goal. Planning should be proportional to the regulation concerning how public services were run. The Director of DPM-PTSP could not operate the public services optimally if there were overlapping regulations. Rule of Law might the solution to bureaucratic challenges in the organization. As a result, transparent, accountable, effective, and efficient public service could be realized.

Regulation by the government of Gorontalo was expected to increase their local own-source revenue through income in the taxation sector. It might contribute to national economic growth as well. Gorontalo should have a distinguishing characteristic as a city offering services. There were numerous banking offices, financing offices, universities, clinics, and drug stores, restaurants, hotels, tourist destinations, night entertainments, service providers, and goods suppliers in Gorontalo. It indicated that investors and micro small medium enterprises were more interested in making an investment in Gorontalo than in other regencies in Gorontalo. In geographic terms, Gorontalo was the provincial capital and in the infrastructural term, the city was well-facilitated, making it one of the strategic locations to invest. In addition, despite its smaller area, Gorontalo remained the most populous city throughout the province.

\section{CONCLUSION}

Our findings stated below, indicated that the planning process should be supported by the Rule of Law aspect. They were: 1) Service mechanism in DPM-PTSP required regulating power to optimize the organization function, 2) Regulation should be constantly reviewed by employees, ensuring their service innovation was legally protected, 3) Regulations available in DPM-PTSP Gorontalo were overlapping. It hampered the director to determine planning standards as one of the corrective acts for services provided by DPM-PTSP, 4) Rule of Law could select the effective mechanism and provide protection for all employees, so future challenges in term of realizing transparent, accountable, effective and efficient public services could be resolved and 5) Optimization in regulation could increase the quality of public service, develop investment climate and accelerate either regional or national economic growth.

\section{SUGGESTIONS}

We proposed several suggestions i.e. 1) The local government may use e-government service to minimize technical error in the implementation of licensing mechanism, 2) The local government should coordinate to the central government and draw both national and international investors' interests in investing in Gorontalo and 3) Licensing mechanism should be simplified to eliminate any overlapping regulation, so investors will be more interested in investing in Gorontalo.

\section{REFERENCES}

[1] Effendi Usman. 2015. Asas-asas Manajeman. Second printing. PT. RajagrafindoPersada.

[2] Law Number 25 of 2009 on Public Services.

[3] Miles andHuberman. 1992. Analisis Data Kualitatif (translated by Tjetjep Rohedi Rosidi). Jakarta: Universitas Indonesia.

[4] Siagan Sondang. 2012. Fungsi-fungsi Manajemen. Jakarta: BumiAksara.

[5] Terry R. George. 2000. Asas-asas Manajemen (translated by Winardi). Bandung.

[6] Peraturan Menteri Dalam Negeri Nomor 24 tahun 2006 tentangPedomanPenyelenggaraanPelayananTerpaduSatuPint u.

[7] Peraturan Menteri Dalam Negeri Nomor 20 tahun 2008 tentang Pedoman Organisasidan Tata Kerja Pelayanan Terpadu di Daerah.

[8] Peraturan Walikota Gorontalo Nomor 4 Tahun 2017 tentang Pelimpahan Kewenangan Pelayanan Perizinandan Nonperizinan 